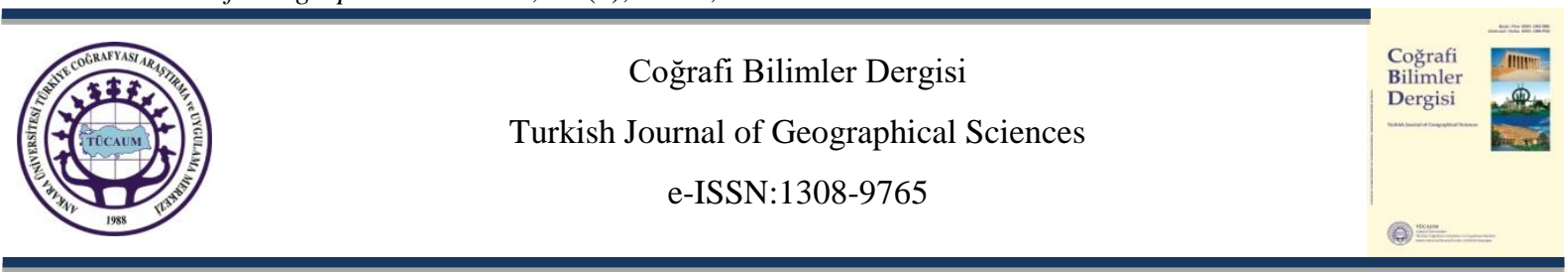

\title{
Akdeniz Üniversitesi Turizm Fakültesi Öğrencilerinin Destinasyon Seçiminde Etkili Olan Çekici Faktörlerin Önem Performans Analizi
}

The Importance-Performance Analysis of Pull Factors Affecting the Touristic Destination's Choice of Students in the Tourism Faculty of Akdeniz University

Zeki Akıncı $^{\text {a }}$, Dilek Aybar*b, Altan Demirel ${ }^{\mathrm{c}}$, Dilara Bahtiyar Sarı ${ }^{\mathrm{c}}$, Emine Nurdan Öksüz ${ }^{\mathrm{d}}$

\begin{tabular}{l} 
Makale Bilgisi \\
\hline Araştırma Makalesi \\
\hline DOI: \\
10.33688/aucbd.949574 \\
\hline Makale Geçmişi: \\
Geliş: 08.06.2021 \\
Kabul: 18.11.2021 \\
\hline Anahtar Kelimeler: \\
Destinasyon \\
Çekici faktörler \\
Önem performans analizi \\
Turizm öğrencileri
\end{tabular}

\begin{tabular}{l} 
Article Info \\
\hline Research Article \\
\hline DOI: \\
10.33688/aucbd.949574 \\
\hline Article History: \\
Received: 08.06.2021 \\
Accepted: 18.11.2021 \\
\hline Keywords: \\
Destination \\
Pull factors \\
Importance-performance \\
analysis \\
Tourism students
\end{tabular}

\begin{abstract}
$\ddot{O} z$
Yoğun küresel rekabetin yaşandı̆̆ı günümüz turizm sektöründe, turistik destinasyonların tercih edilmesinde, destinasyonların sahip oldukları çekici faktörlerin önemli bir etkisi bulunmaktadır. Bu çalışmada, Antalya ilinde bulunan Akdeniz Üniversitesi'nde turizm eğitimi alan 426 ögrenciden anket tekniği ile veriler toplanmış ve Önem-Performans Analizi (ÖPA) yöntemiyle destinasyonda algılanan çekici faktörlerin önemi ve çekici faktörlerin uygulanma performanslarının tespit edilmesi amaçlanmıştır. Elde edilen sonuçlara göre, yüksek önem ve yüksek performans gösterilen doğal güzellikler, kültür, konaklama hizmetleri ve destinasyonun cazip alanlart destinasyonun korunması ve sürdürülmesi gereken yönleri olarak; buna karşıllk hem düşük önem hem de düşük performans gösterilen destinasyon danışma hizmetleri, destinasyondaki yerlere sınırsız ziyaret, bilgilendirici levha ve simgeler, ilginç/farkl yerel gelenekler düşük öncelik verilmesi gereken; yoğunlaşılması gereken özellikler olarak ulaşma ă̆ının yaygınlı̆̆l, destinasyonun temizliği, yiyecek-içecek işletmelerin kalitesi; düşük önem verilmesine rağmen yüksek performans gösterilen ve kaçınılması gereken özellikler ise iş/ticaret, destinasyonun tarihi ve birden çok alışveriş firsatı olarak saptanmıştır.
\end{abstract}

\footnotetext{
*Sorumlu Yazar/Corresponding Author: dilekaybar@akdeniz.edu.tr

a Akdeniz Üniversitesi, Turizm Fakültesi, Turizm İşletmeciliği Bölümü, Antalya, Türkiye, https://orcid.org/0000-0001-86433429 .

b Akdeniz Üniversitesi, Turizm Fakültesi, Turizm İşletmeciliği Bölümü, Antalya, Türkiye, https://orcid.org/0000-0002-13353601 .

c Antalya AKEV Üniversitesi, Meslek Yüksekokulu, Seyahat-Turizm ve Eğlence Hizmetleri Bölümü, Antalya, Türkiye, https://orcid.org/0000-0002-1010-4116.

c Gaziantep Üniversitesi, Turizm ve Otelcilik Meslek Yüksekokulu, Gaziantep, Türkiye, https://orcid.org/0000-0002-06450585 .

d Akdeniz Üniversitesi, Demre Dr. Hasan Ünal Meslek Yüksekokulu, Seyahat-Turizm ve Eğlence Hizmetleri Bölümü, Antalya, Türkiye, https://orcid.org/0000-0002-6091-3069.
} 


\section{Giriș}

Bireyler, boş zamanlarını değerlendirme amacıyla "eğlenmek, gezip görmek, sosyalleşmek, kendini geliştirmek, sağlıklı ve zinde kalmak, bilgi ve kültür edinmek, heyecan ve macera yaşamak gibi" farklı güdülerle seyahatlere katılmaktadır (Cordes, 2013). Kişilerin seyahat kararı vermesi birçok aşaması olan karmaşık bir süreci içermekte olup, seyahat etmeye neden olan güdü, karar verme sürecinin başlangıç noktasıdır (Mansfeld, 1992). Bu noktada bireyin içsel seyahat motivasyonu ile ilgili onu seyahat etmeye yönlendiren itici faktörler gelmektedir. Bu süreci, bireyin içsel seyahat motivasyonu ile oluşan beklentilerini karşılayacak dışsal seyahat motivasyonu ile ilgili çekici faktörler hakkında bilgi edinme, değerlendirme ve destinasyon alternatifleri arasından en uygun olanını tercih etme izlemektedir.

Seyahate karar verme sürecinde, bireylerin satın alma davranışlarının belirlenmesinde itici ve çekici faktörler önemli rol oynamaktadır (Kim vd., 2003). Söz konusu itici ve çekici faktörler, turist davranışına neden olan güdüleri anlamak açısından basit ve sezgisel bir yaklaşım sağlamaktadır. İçsel seyahat motivasyonları olarak adlandırılan itici faktörler, insanları evlerinden sürekli yaşadıkları yerlerden uzağa iten ve seyahat etmek için ilk motivasyonu sağlayan iç etkenlerdir (Schott, 2004). Turist motivasyonunun incelenmesinde itici faktörlere odaklanılması önerilmektedir (Dann, 1977). Meisel ve Cottrell (2003), dinlenme, rahatlama ve kaçma isteğini genel itici faktörler arasında olduğunu belirtmektedir. İtici faktörler bireylerin seyahat kararını ve destinasyon tercihini etkileyen sezgisel güçler olurken, çekici faktörler somut sebepler olmaktadır. Crompton (1979) ise, tatilcinin tatile çıkma merakını itici faktörlerin tek başına açıklamaya yetmeyeceğini, aynı zamanda önerilecek potansiyel destinasyonun çekici faktörleriyle birlikte işleyebileceğini ortaya koymuştur. Seyahat etmek isteyen turistlerin destinasyon tercihi ve sonrasında satın alma kararları üzerinde ekonomik, sosyo-kültürel ve demografik özelliklerinin yanı sıra turisti seyahat etmek için harekete geçiren itici faktörlerle örtüşen destinasyona özgü çekici faktörlerin belirleyici bir etkiye sahip olduğu bilinmektedir (Demir, 2010: 1042). Çekici faktörleri “destinasyonun sahip olduğu özellikler, atraksiyonlar, öznitelikler” olarak tanımlamak mümkündür (Klenosky, 2002). Uysal vd. (2008)'ne göre çekici faktörler, tarihi kaynaklar, tabii çevre, sosyo-fiziksel yapı vb. unsurlardır. Çekicilik olarak tanımlanan tüm somut unsurlar fiziki ve beşeri coğrafyanın konusu olmakla birlikte, insanların çevre algısı üzerinde etkilidir (Karadağ ve Turut, 2013). Yapılan bu çalışmalar, turizm eğitimi alan öğrencilerin bakış açısına göre, söz konusu destinasyonun çekici unsurların önemi ve performansı üzerine yapılandırıldığı için itici faktörler araştırma kapsamına dâhil edilmemiştir.

Turizm destinasyonlarında sürdürülebilirliğin sağlanmasında turistlerin seyahat motivasyonunu belirleyen itici faktörlerin yanı sıra seyahat edeceği destinasyonun tercihini ve seçimini etkileyen çekici faktörlerin (tarihi, doğal, yapay, rekreasyonel vs.) belirlenmesi yaşamsal bir önem taşımaktadır. $\mathrm{Bu}$ bağlamda, destinasyonların çekici özelliklerinin belirlenmesi, kıt kamusal ve/veya özel kaynakların rasyonel bir şekilde değerlendirilmesini, pazar bölümlendirmesinin doğru bir şekilde yapılmasını ve pazarlama karması elemanlarının daha etkin, verimli ve etkili bir şekilde kullanılmasını sağlamaktadır. 


\section{Kavramsal Çerçeve}

\subsection{Destinasyon Çekiciliği}

Farklı bilimsel disiplinler bağlamında birçok farklı tanımı yapılan destinasyon kavramı birçok yazar tarafindan; ekonomik alan (Olal1, 1990: 85) seyahat amacı (Gunn, 1994: 27), turizm bölgesi (Kozak, 2002: 511) fiziksel sınırlar (Alvarez, 2007: 282), çekim yeri (Çakıcı ve Aksu, 2007: 1), coğrafi özellikler (Friedmann ve Weaver, 1980: 31), kültür, iklim, marka, imaj (Bahar ve Kozak, 2012: 35), deneyim ve coğrafi alan (Buhalis, 2000: 97) açısından ele alındığı görülmektedir. Örneğin; Buhalis (2000: 97) destinasyon kavramını turistik ürünlerin karmaşık bir şekilde yer alan ve turistlere bütünleşik bir deneyim sunan yer olarak ifade ederken, daha ayrıntılı bir şekilde ele alan Bahar ve Kozak (2012: 41), farklı aktivitelerin yer aldığı, doğal çevresel ve kültürel zenginlikleri bulunan, ulaşım, konaklama ve iletişim altyapısı bulunan, yeme-içme hizmetlerinin sunulduğu, kamusal hizmetlerin de sağlandığı, markası ve imaja sahip coğrafi bir alan olarak tanımlamışlardır. Farklı yaklaşımlar nedeniyle literatürde destinasyon hakkında birçok tanım yer almaktadır. Kısa ve genel olarak, destinasyonu, belirli amaçlar doğrultusunda gidilen ve deneyimlerin yaşanıldığ “yer" olarak tanımlamak mümkündür. Bahsedilen yer, kıta, bölge, şehir, ada, köy (Öter ve Özdoğan, 2005) ve hatta bir yolcu gemisi, destinasyon olarak kabul edilebilir (Buhalis, 2000: 7).

Seyahat motivasyonu kavramı, turistlerin seyahat ihtiyaçlarının ve davranışlarının anlaşılmasında önemli bir yaklaşımdır. Seyahat motivasyonları ile ilgili çalışmalarda en çok kabul gören "itici ve çekici" motivasyon teorisinin temel varsayımı; belirli itici ve çekici faktörlerin bireyleri seyahat etmeye teşvik etmesidir. (Yousefi ve Marzuki, 2012: 169). İtici (içsel) faktörler, insanları seyahat etmeye teşvik eden sosyo-psikolojik motivasyonlardır. Bunlara örnek olarak bulunulan ortamdan kaçma, dinlenme, macera, statü, sosyal - fiziksel - ruhsal iyilik hali gibi unsurlar verilebilir. Çekici (dışsal) faktörler ise insanların tatil amacıyla belirli bir destinasyonu tercih etmesini sağlayan cezbedici unsurlardır (Oh vd., 1995: 124). Belirli destinasyona ait güneş, sahiller, plajlar, yapay alanlar, spor, kültürel aktiviteler gibi özellikler, çekici faktörlere örnek gösterilebilir (Klenosky, 2002: 385). Bir destinasyon ne kadar çekici seyahat motivasyonu faktörünü karşılayacak ve tatmin edecek çekici faktör çeşitliliğine sahip ise, o kadar çok turistin kendisini tercih etmesini sağlayacaktır.

Çekicilik, bir nesnenin bir özneyi belirli bir bilgi stili bağlamında tatmin olması için niyet ve eylemde bulunmasını sağlayan cezbetme durumunu ifade eder. Chien (2016: 44)'e göre, destinasyonun önemli bir öğesi olan çekicilik, turistlerin ihtiyaçlarını karşılayabilecek rekreasyon ${ }^{1}$ kaynaklarının ve insanlar tarafından özel olarak yaratılan cazibe alanlarının özelliklerini veya ziyaret etme isteklerini artırabilecek hizmet ve tesisleri göstermektedir. Diğer bir tanıma göre, çeşitli unsurların bir araya gelmesiyle oluşan (Kim, 2014: 34) çekicilik, seyahat edenlerin tercihini belirleyici şekilde etkileyen ve turistik yere ziyaretçi akışını sağlayan temel unsurlardandır (Bağıran, 2015: 12). Bunlar; doğal unsurlar (iklim, flora, fauna, sahiller, parklar, dağlar vb.), insan eliyle yapılanlar (anıtlar, Eyfel Kulesi, dini yerler vb.) ve kültürel unsurlar (müzeler, tiyatrolar, festivaller, sanat galerileri, gastronomi vb.) sayılabilmektedir (UNWTO, 2019: 1). Bu tanımların içerikleri bağlamında, katılım motivasyonunun öncüsü olan bir destinasyonun çekiciliği (Ke, 2012: 953), sadece o bölgenin doğası ve insan kaynakları değil, aynı zamanda turistlere hitap eden çekiciliği inşa etmek için alanın tanıtımını ve kurulmasını da 
içerdiği ifade edilebilir (Buckley vd., 2012: 106). Bu nedenle turistlerin beğenisine yeni destinasyonlar sunmak ve mevcut destinasyonların sahip olduğu çekicilikleri en üst düzeye çıkarmayı amaçlamak gerekmektedir (Ulama, 2015: 232-233).

Akademisyen araştırmacılarla birlikte turizm sektöründeki kamusal ve profesyonel yöneticiler, turistlerin ziyaret ettikleri destinasyonda ne tür çekicilikleri görmek istedikleri ve nelerden memnun kalıp kalmadıkları konusunda bilgi sahibi olarak gerekli değişiklikleri, çeşitlendirmeleri ve iyileştirmeleri yaparak destinasyonu daha çekici hale getirmeye çalışmaktadırlar. Böylece, destinasyonları ziyaret edecek olan turistlerin beklenti, istek ve ihtiyaçlarının günden güne farklılık göstermesi ve değişen bu beklentilere ayak uydurmak için destinasyonları daha çekici bir hale getirmek için destinasyonlara eklemeler yaparak destinasyonun çeşitlendirilmesiyle ziyaretçi sayısının arttırılması sağlanabilir (Arıtan ve Akyüz, 2015: 196). Binlerce destinasyon arasından sıyrılarak farklı ve özgün değerler ortaya koyabilmek, bir destinasyonun pozitif bir imaj ve değer kazanmasında ve bunun sonucunda tercih edilmesinde önemli bir faktördür (Ünal ve Binbaşığlu, 2015: 4). Örneğin, Türkiye'ye gelen turist sayısından daha fazla turist çeken ve deniz kıyısı bile olmayan Fransa'nın başkent Paris, iyi korunmuş tarihsel ve doğal çekiciliklerin yanı sıra alışveriş, kültür-sanat, moda ve eğlence merkezleri ile bir cazibe merkezi olarak tercih edilmektedir. Turistlere belirli bir destinasyona seyahat etme eylemi için büyük bir motivasyon sağlayan (Lo ve Jim, 2015: 59) ve Hall vd. (2003)'ne göre "turistik terroir" olarak tanımlanan çekicilik turizm sisteminde bir destinasyonun kalıcı ve sürdürülebilir olmasında birincil unsurdur.

Araştırma konusu olan Antalya destinasyonu, Türkiye'nin güneyinde ve deniz kenarında bir sahil kentidir (Şekil 1). Ülkenin en temiz ve en güzel kıyıları arasında bulunan Antalya ili kıyıları, Akdeniz kıyı şeridinin (1.577 km) \%35'ini (450 km) oluşturmaktadır (Sarı ve Aligil, 2016). Antalya, sahip olduğu eşsiz doğal ve tarihi güzelliklerin yanı sıra modern alt ve üst yapısı ile Türkiye'nin ve hatta dünyanın sayılı önemli destinasyonları arasında yer almaktadır. 2019 yılı itibarıyla, nüfusu 2.511.700 kişiye (TUIK, 2020a) ulaşan Antalya ilinin sahip olduğu turizm ile ilgili temel bilgiler Çizelge 1'de gösterilmekte olup, İspanya'nın tamamından daha fazla 5 yıldızlı konaklama tesisine sahiptir (Turizmaktuel, 2019).

Çizelge 1. Temel bilgiler

\begin{tabular}{|c|c|c|c|}
\hline & Antalya İlinde & Türkiye'de & Oran \\
\hline Belgeli Yatak Sayısı (Toplam) & 645,960 & $1,764,340$ & $36,6 \%$ \\
\hline (Turizm Yatırım ve İşletme Belgeli) & $(509,316)$ & $(1,188,658)$ & \\
\hline (Belediye Belgeli) & $(136,644)$ & $(575,682)$ & \\
\hline 5 Yıldızlı Konaklama İşletmesi & 407 & 848 & $48.0 \%$ \\
\hline Ağırlanan Turist (tatil amacıyla gelen) & 14 milyon 650 bin & 51 milyon 860 bin & $32.51 \%$ \\
\hline
\end{tabular}

Kaynak: TUİK, 2020b: KTB, 2020 


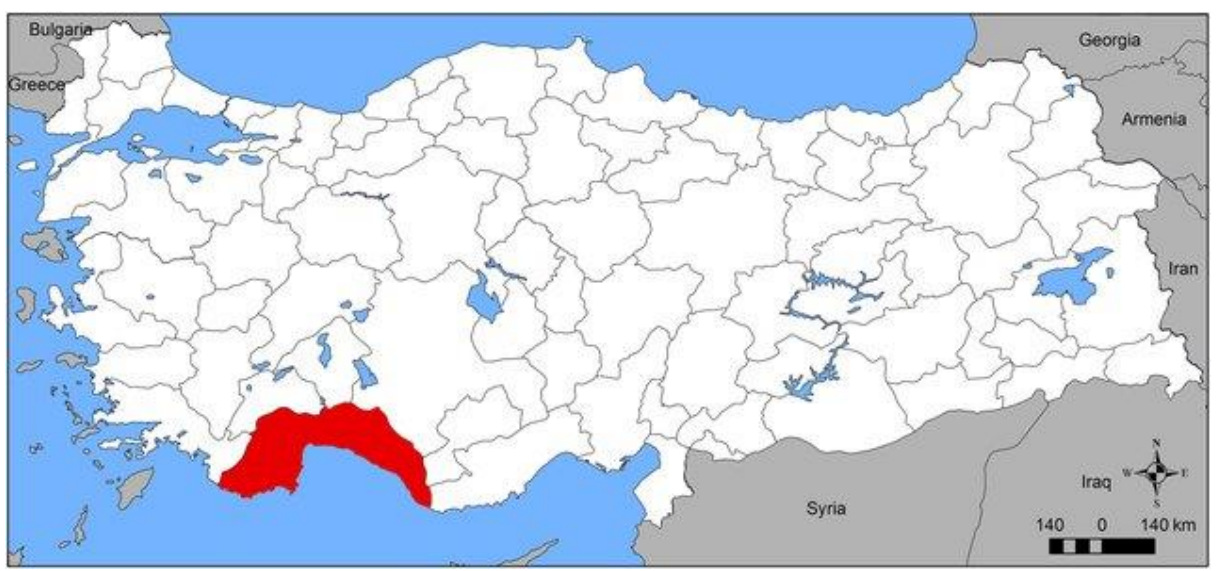

Şekil 1. Antalya ilinin Türkiye'deki coğrafi yeri (kırmızı boyalı alan)

Kaynak: https://en.wikipedia.org/wiki/Antalya_Province

\section{Amaç, Veri, Yöntem}

\subsection{Kantitatif Yöntem}

Kantitatif araştırma yönteminde, araştırma evreninin araştırma konusu hakkındaki fikrinin yönü sorgulanmakta; evreni temsil edecek örneklemden araştırılan konuya ilişkin sayısal veriler elde edilmektedir. Bu araştırmanın temel amacı, Akdeniz Üniversitesi’nde turizm eğitimi alan öğrencilerin Antalya ilinde sunulan turistik hizmetlerin önem-performans analizi yöntemiyle analiz edilerek, sahip olunan çekici özellikler ve hizmetler hakkında mevcut durumun ortaya çıkarılmasıdır.

\section{Önem Performans Analizi (ÖPA)}

Çalışmada kullanılan önem performans analizi (ÖPA), ilk olarak Martilla ve James (1977) tarafından otomobil endüstrisinin performansını analiz etmek için kullanılmıştır. ÖPA, hizmet kalitesini arttıran unsurların tespit edilmesiyle ilgili olan ve müssteri memnuniyetini etkileyen ürün özelliklerinin ortaya konulması hususunda araştırmalarda yoğun ilgi gören bir tekniktir (Bacon, 2003). ÖPA tekniği ile incelenen ürün özelliklerinin müşteriler açısından neyin daha önemli olduğunun tespit edilebilmesinde, ürün performansının karşılaştırılarak etkin pazarlama stratejileri geliştirilebilmesinde fayda sağladığı (Deng, vd., 2008) gibi, işletme yöneticilerinin de kısıtlı kaynaklarla daha akılcı kararlar alarak müşteri memnuniyetinin arttırılmasını sağlamaktadır. ÖPA'nın dayandığı temel olan inceleme alanına ait özelliklerin önemi ve bu özelliklere ilişkin performans algılarının bir matris üzerinde karşılaştırılarak değerlendirilmesi sayesinde özellikle kısıtlı kaynakların kullanımı ve dağıtımı ile alakalı yönetimsel hususlarda daha doğru kararlar verilebilmektedir (Albayrak ve Caber, 2011: 627). Bunlara ilaveten teknik, uygulanması az maliyetli ve kolay yorumlanabilir olması (Bruyere vd., 2002) nedeniyle birçok alanda araştırmacılar tarafindan yoğun ilgi görmektedir.

ÖPA yöntemi, hizmet özelliklerinin önemini ve müşteri memnuniyetini değerlendirmek için turizm ve konaklama endüstrisinde de (Go ve Zhang, 1997; Hollenhorst vd., 1986) kullanılmaktadır. ÖPA, tatil destinasyonlarının değerlendirilmesinde Pike ve Ryan (2003) ve restoranların yemek yeme deneyimi niteliklerinin değerlendirilmesinde Hu vd. (2009), restoran konumlandırmada Keyt vd. (1994) 
ve Hsu vd. (1997), turizm politikasını formüle etmede ve değerlendirmede Evans ve Chon (1989), turistlerin otel endüstrisi hakkındaki algılarını tanımlamada Lewis (1985), müşteri memnuniyetini arttırmak için araçları belirleme konusunda Almanza vd. (1994) ve hizmet sağlayıcıların otel endüstrisindeki kaliteli hizmet beklentilerinin müşterilerin algılarını belirlemede Martin (1995) tarafından kullanılmıştır.

Martilla ve James (1977: 78)' e göre ÖPA tekniği, işletme yöneticilerinin göz önünde bulundurması gereken eylem düzeylerini tanımlamaktadır. Sistem dört bölümden oluşmaktadır (bkz. Çizelge 2). Birinci bölümde yer alan özellikler önem açısından yüksek ve performans açısından düşük olarak derecelendirilmektedir. Bu bölüm, yöneticilerin servis veya ürün performansı seviyelerini arttırmaya yönelik acil önlemleri alması, performans geliştirici faaliyetlerin planlanması ve bu bölüme yoğunlaşması gerekmektedir. İkinci bölüm, hem performans hem de önem açısından yüksek puan alan nitelikleri temsil etmektedir. Bu bölümde, şirketin rekabet avantajlarını ve ticari büyümeyi sürdürmek için aynı performans seviyelerini korumalı ve sürdürmelidirler. Üçüncü bölümde, söz konusu özellikler hem önem hem de performans açısından düşük öncelikli olarak değerlendirmektedir. Bu nedenle, yönetimin düşük önceliklerin söz konusu olduğu bu özellikler üzerinde daha fazla işlem yapmamalı ve müşterilerin düşük önem verdiği özelliklere yöneticilerin kıt olan kaynakları yönlendirmemelidir. Dördüncü bölüm, performansı yüksek ancak önemi ve önceliği düşük olan özellikleri belirtmektedir. Bu seviyede işletme yöneticileri bu bölümde kullanılan kıt kaynakları işletmedeki diğer önemli faaliyetlere öncelikle birinci bölüme yönlendirmelidir (Obonyo vd., 2013: 190-191).

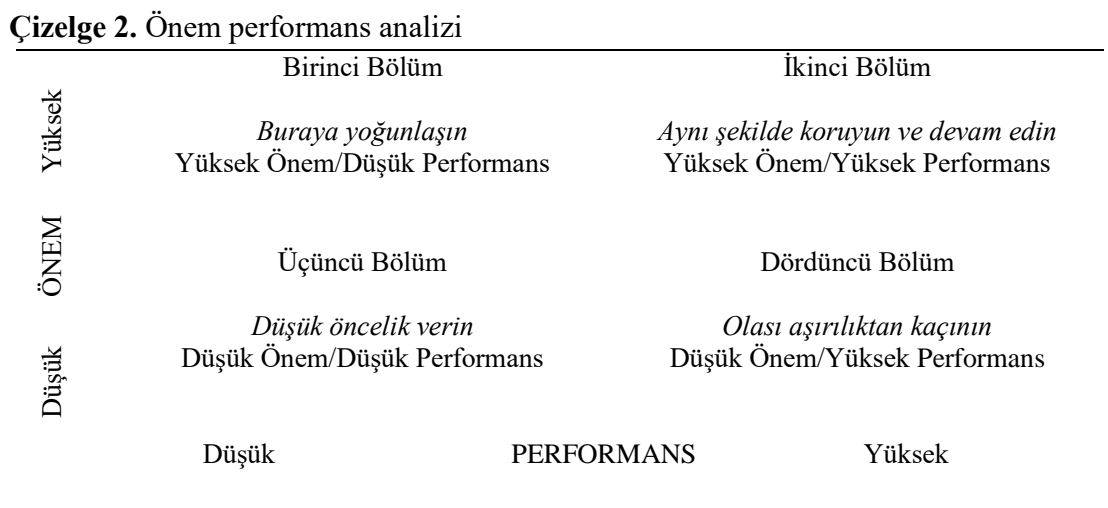

Nicel araştırma deseninde hazırlanan anket sorularının hazırlanmasında, bu araştırmanın örnek modelini oluşturan Albayrak ve Caber (2011)'e ait destinasyon yönetiminde önem performans konulu makaleden faydalanılmıştır. İki bölümden oluşan anket formunun ilk bölümünde demografik özelliklere ilişkin sorulara yer verilmiştir. İkinci bölümde ise Antalya destinasyonuna yönelik özelliklerin ve sunulan hizmetlerin önem ve performans algılarına ilişkin faktörlerle ilgili 24 ifadeye yer verilmiştir. Bu bölümde katılımcılara çok kötüden (1) çok iyiye (5) kadar olan aralıkta değerlendirmeleri istenmiştir. Saha çalışması, Akdeniz Üniversitesi’nde turizm ile ilgili bölümlerde eğitim alan öğrencilere gönüllük esasına dayalı olarak gerçekleşmiştir. Anket çalışması Akdeniz Üniversitesi'nde turizm alanlarında eğitim gören 426 öğrenciye, 2019 Eylül-Kasım ayları arasında uygulanmıştır. Elde edilen anketlerin analizi için SPSS 22.0 paket programından faydalanılmıştır. 
Çizelge 3. Faktör analizi

\begin{tabular}{|c|c|c|c|}
\hline \multicolumn{4}{|c|}{ Faktörler } \\
\hline İfadeler & $\begin{array}{l}\text { Erişilebilirlik ve } \\
\text { kaliteli hizmet }\end{array}$ & $\begin{array}{c}\text { Somut ve soyut } \\
\text { değerler }\end{array}$ & $\begin{array}{l}\text { Ağırlama hizmetleri ve } \\
\text { iş/alışveriş imkânı }\end{array}$ \\
\hline 23)Bilgilendirici levha ve simgeler & ,780 & & \\
\hline 21)Yiyecek-İçecek işletmelerinin kalitesi & ,728 & & \\
\hline 24)Ulaşım ağının yaygınlığı & 665 & & \\
\hline 22)Destinasyon danışma hizmetleri & ,641 & & \\
\hline 20)Destinasyonun temizliği &, 596 & & \\
\hline 8)Destinasyondaki yerlere sınırsız seyahat &, 560 & & \\
\hline 16)Destinasyonun cazip alanları & & ,704 & \\
\hline 7)Doğal güzellikler & & 652 & \\
\hline 13)Destinasyonun tarihi & & 615 & \\
\hline 17)İlginç/farklı yerel gelenekler & & 610 & \\
\hline 12)Kültür (Yiyecek, içecek, dil,din) & &, 539 & \\
\hline 18)Birden çok alışveriş firsatı & & & ,720 \\
\hline 14)İs/ticaret & & & 606 \\
\hline 15)Konaklama & & &, 585 \\
\hline Güvenilirlik Katsayısı (Cronbach Alpha) & ,796 & ,743 & ,701 \\
\hline Varyans açıklama oranı (\%) & 19,960 & 15,076 & 12,102 \\
\hline \multicolumn{2}{|c|}{ Toplam varyansı açıklama oranı (\%): 47,138 KMO: ,895 } & \multicolumn{2}{|c|}{ Toplam ölçek güvenilirlik değeri: ,846 } \\
\hline
\end{tabular}

Elde edilen üç faktörün varyans açıklama oranı \% 47,138 olarak elde edilmiş, ölçeğin boyutlar bazında güvenilirlikleri 0.701 ile 0.796 arasında değişiklik göstermektedir. Literatürde Cronbach'ın alfa katsayısının 0-1 arasında değişkenlik gösterdiği, değerlendirme kriterlerine göre " $0.00 \leq \propto<0.40$ ise ölçek güvenilir değil, $0.40 \leq \propto<0.60$ ise ölçek düşük güvenirlikte, $0.60 \leq \propto<0.80$ ise ölçek oldukça güvenilir ve $0.80 \leq \propto<1.00$ ise ölçek yüksek derecede güvenilir bir ölçek" olarak değerlendirildiği belirtilmektedir (Tavşancıl, 2005; Şahin ve Bekir, 2016). Yine benzer olarak Ural ve Kılıç (2006: 286) güvenilirlik katsayısının 1'e yaklaştıkça güvenilirliğin arttığını belirtmiştir. Ortaya çıkan toplam ölçek güvenilirlik değeri ,846 olarak yüksek güvenilir ölçek şeklinde elde edilmiştir.

\subsection{Araştırmanın Evren ve Örneklemi}

Araştırmanın uygulama alanı olarak Antalya ilinin tercih edilmesinin en önemli sebepleri; Türkiye'nin önemli destinasyonlarından biri olması aynı zamanda Akdeniz bölgesini temsil etme gücüne sahip olması, gelir, turist sayısı ve konaklama kapasitesi bakımından yeterli bir destinasyon olması ve öğrencilerin üniversite tercihlerinde etkili bir şehir olmasıdır. Öğrenciler, öğrenim amacıyla, 
uzun bir tatil sırasında eve dönmeden turistik yerde zaman geçirdiği ve boş zamanlarında turistik faaliyetlere katılması gibi sebeplerden dolayı turizm destinasyonu çalışmalarında turist olarak değerlendirilmiş̧tir (Abdullateef ve Biodun, 2014). Olcay ve Doğan (2015), üniversite eğitimi amaciyla yaşadıkları yerlerden en az 24 aylığına ayrılan ve başka şehre yerleşen öğrencilerin de potansiyel turistler olarak nitelendirilebileceğini ve söz konusu şehri başkalarına tavsiye etme oranlarının şehrin imajını olumlu etkilediğini belirtmektedir. Destinasyon üzerinde yapılan bilimsel araştırmaların farklı paydaşların bakış açısıyla ele alınmasının önemli ve gerekli olması (Ayaz ve Bakar, 2020) nedeniyle araştırmanın örneklemi olarak Antalya ilindeki en eski yükseköğretim hizmeti veren Akdeniz Üniversitesi'nin Turizm Fakültesi öğrencileri seçilmiştir.

Araştırmanın evrenini Akdeniz Üniversitesinde Turizm Fakültesi'nde 2019-2020 akademik y1lı içinde eğitim alan öğrenciler (2332 kişi) oluşturmakta olup; rastgele örneklem tekniğiyle 426 kişiye ulaşılmıştır. Bu kişi sayısı, Yazıcıŏglu ve Erdoğan'ın (2004) aşağıdaki formülasyona ve örnek büyüklüğü hesaplama aracına (Raosoft, 2019) göre hesaplanmış örneklem büyüklügü (\%95 güven seviyesinde 330 öğrenci) çizelgesinde, $\% 5$ 'lik örneklem hatası ile yeterli olduğu görülmektedir.

\section{Bulgular}

Araştırmaya katılan öğrencilerin profili Çizelge 4'te gösterilmektedir.

\begin{tabular}{lll} 
Çizelge 4. Öğrenci profili & \\
\hline \multirow{3}{*}{ Cinsiyet } & $\mathrm{N}$ & Yüzde \\
& 171 Kadın & $\% 40$ \\
Bölüm & 255 Erkek & $\% 60$ \\
& Turizm İșletmeciliği: 138 & $\% 32,2$ \\
& Gastronomi ve MS: 115 & $\% 26,9$ \\
& Turizm Rehberliği: 95 & $\% 22,2$ \\
\multirow{3}{*}{ Sınıf } & Rekreasyon Yönetimi: 78 & $\% 18,2$ \\
& 1. Sinıf: 148 & $\% 34,6$ \\
& 2. Sinıf: 131 & $\% 30,6$ \\
& 3. Sinıf: 73 & $\% 17,1$ \\
Milliyet & 4. Sinıf: 74 & $\% 17,3$ \\
& T.C.: 407 & $\% 95,1$ \\
& Diğer Ülke: 19 & $\% 4,9$ \\
\hline
\end{tabular}

Çizelge 5'te Antalya destinasyonunda sunulan önem ve performans ortalamalarına yer verilmiştir. Performans ortalamaları çok kötüden (1), çok iyiye (5) kadar olan aralıkta, önem ortalamaları az önemliden (1) çok önemliye (5) kadar olan aralıkta hazırlanmıştır. Destinasyonun performans ve önem ortalaması bulgularına göre; en düşük ifade "destinasyon danışma hizmetleri" ifadesi olduğu tespit edilmiştir. En yüksek ifade ise somut ve soyut boyutunda yer alan "destinasyonun cazip alanları" ifadesidir. 
Çizelge 5. Ölçeğin önem ve performans ortalamaları

\begin{tabular}{llcc}
\hline \multicolumn{1}{c}{ Kullanılan İfadeler } & Önem Ort. & Performans Ort. \\
1. Doğal güzellikler & 4,06 & 4,40 \\
2. Destinasyondaki yerlere sınırsız ziyaret & 3,54 & 3,44 \\
3. Kültür (yiyecek, içecek, dil, din) & 3,80 & 3,83 \\
4. Destinasyonun tarihi & 3,58 & 3,95 \\
5. İş/ticaret & 3,39 & 3,68 \\
6. Konaklama & 3,83 & 3,93 \\
7. Destinasyonun cazip alanları & $3,87 * *$ & $4,10 * *$ \\
8. İlginç/farklı yerel gelenekler & 3,55 & 3,49 \\
9. Birden çok alışveriş firsatı & 3,45 & 3,84 \\
10. Destinasyonun temizliği & 3,80 & 3,59 \\
11. Yiyecek-İçecek işletmelerinin kalitesi & 3,77 & 3,54 \\
12. Destinasyon danışma hizmetleri & $3,42 *$ & $3,23 *$ \\
13. Bilgilendirici levha ve simgeler & 3,58 & 3,53 \\
14. Ulaşım ağının yaygınlığı & 3,84 & 3,64 \\
\hline **en yüksek ortalama değeri * en düs̆̈̈k ortalama değeri & &
\end{tabular}

**en yüksek ortalama değeri * en düşük ortalama değeri

Erişilebilirlik ve kaliteli hizmet alt boyundaki ifadelerden biri olan "destinasyon danışma hizmetleri" ifadesi katılımcılar tarafından en düşük bulunmuştur, bu yönüyle iyi bir danışma hizmeti sunamayan destinasyon erişilebilirlik ve ulaşılabilirlik bakımından olumsuz etkilenir. Özellikle bu hizmetin günümüzde daha çok dijital ortamda verilmesinden dolayı destinasyona yönelik sanal sayfaların sürekli güncel olması gerekmektedir. Somut ve soyut değerler alt boyutundaki ifadelerden biri olan "destinasyonun cazip alanları" ifadesi ise katılımcılar tarafından en yüksek bulunmuştur. Bu bağlamda Akdeniz bölgesinde yer alan Antalya ili, sahip olduğu eşsiz güzellikler sayesinde turistik destinasyon olarak birçok turist tarafından çekici bulunmaktadır. Anketi cevaplayan öğrencilerin de \% 66,9'u "Antalya'daki Üniversiteleri tercih ederken destinasyonun etkisi oldu mu?" sorusunu "evet" olarak cevaplamıştır. Antalya destinasyonunun gelişimine ilişkin sorulan açık uçlu soruya istinaden, anketi cevaplayan öğrencilerin \% 39,5'i altyapı ve ulaşımın, \% 16,2'si yeşil-temiz ve bakımlı alanların, \%12,3'ü reklam ve tanıtım faaliyetlerinin geliştirilmesini önermiştir. Diğer öneriler fiyatların daha uygun olması, sanatsal etkinliklerin ve festivallerin arttırılması, müşteri odaklı ve sürdürülebilir yatırımların artması, esnafın ve yerel halkın bilinçlendirilmesi ve desteklenmesi, turizmin dört mevsime yayılmasının sağlanması ve teknolojinin geliştirilmesi şeklindedir.

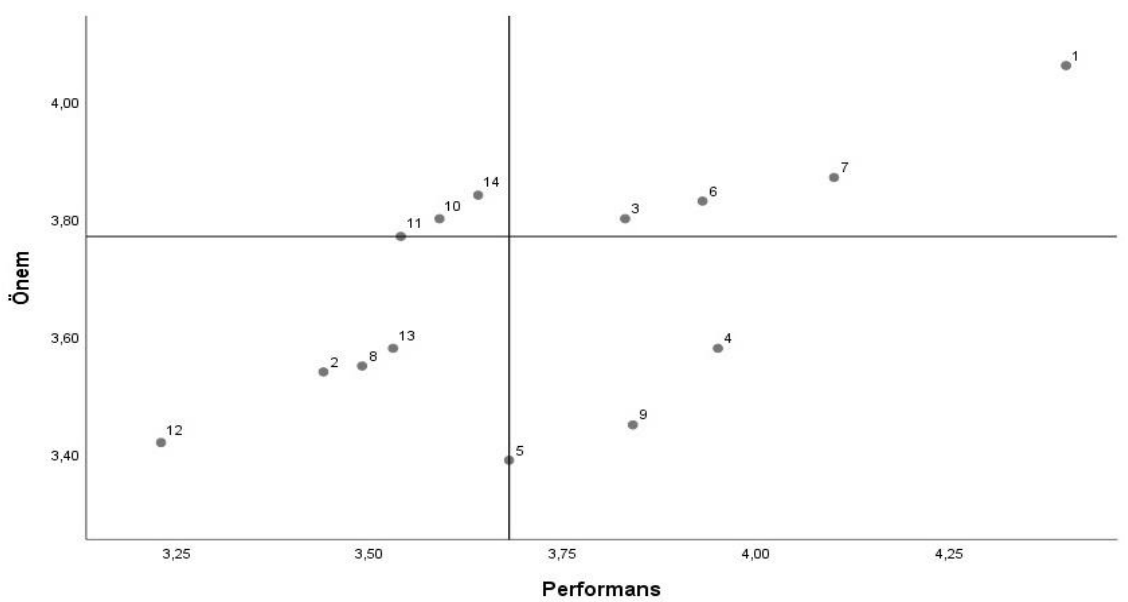

Şekil 2. Önem performans analizine göre ifadelerin dağılımı 
Önem ve performans matrisinin oluşması için yapılan dağılım Şekil 2'de gösterilmiştir. İlk olarak ifadelerin önem ve performans ortalamaları alınmıştır. İkinci olarak belirlenen ifade ortalamaların kesme noktalarını belirlemek için ifade ortalamalarının medyanı alınmıştır. Merkezi eğilimin bir ölçüsü olarak medyan değerleri, teorik olarak ortalama değerine tercih edilmektedir; çünkü ortalama, gerçek bir aralık ölçeği olarak görülmeyebilmektedir (Silva ve Fernandes, 2011: 312). Bu sebeple medyan değerleri alınarak matris oluşturulmuştur.

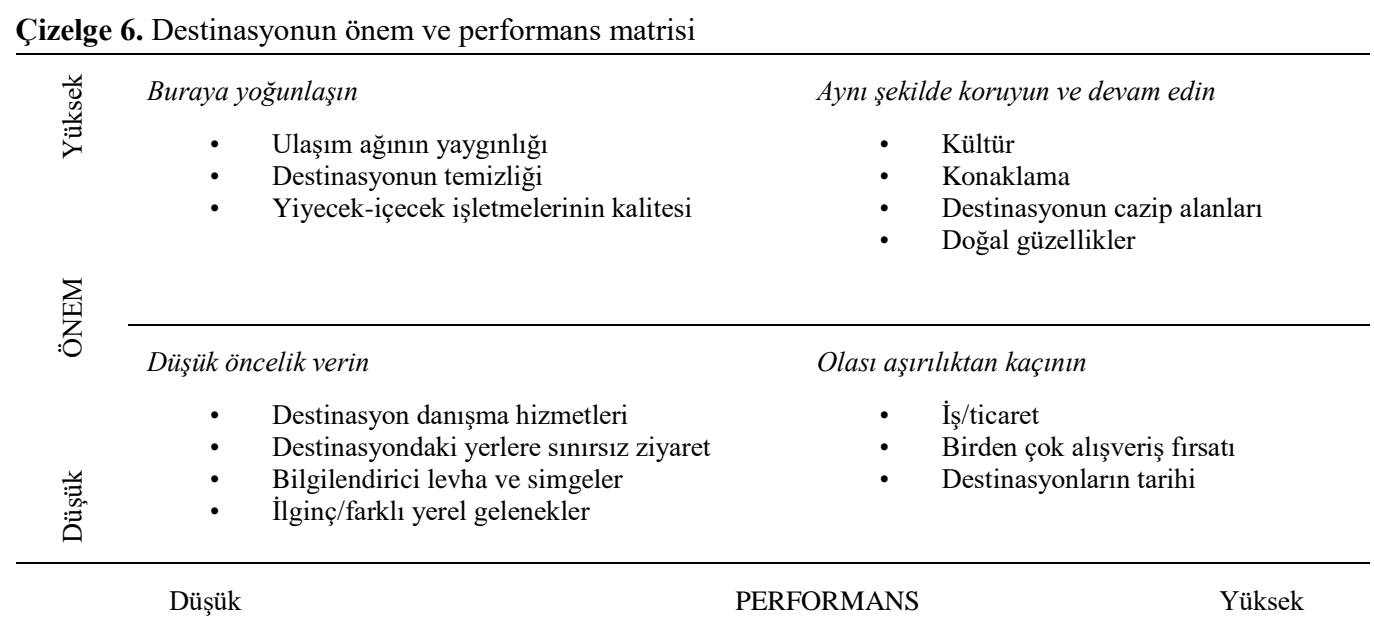

Çizelge 6'da görüleceği üzere önem düzeyi yüksek görülürken, performans bakımından düzeyi düşük görülen ve yoğunlaşılması gereken alanlar "ulaşma ağının yaygınlı̆̆ı, destinasyonun temizliği, yiyecek-içecek işletmelerinin kalitesi" olarak belirlenmiştir. "Kültür, konaklama, destinasyonun cazip alanları, doğal güzellikler" matrisin korunması gerekenler bölümünde yer almaktadır. Bu maddeler önem ve performans bakımından yüksek düzeyde görülmektedir. "Destinasyon danışma hizmetleri, destinasyondaki yerlere sınırsız ziyaret, bilgilendirici levha ve simgeler, ilginç/farklı yerel gelenekler" matrisin düşük öncelik verilmesi gereken bölümünde yer almaktadır. Bu bölümde hem önem hem de performans düzeyinin düşük olduğu görülmektedir. "İş/ticaret, birden çok alışveriş firsat1, destinasyonların tarihi” ise matrisin önem düzeyi bakımından düşük, performans bakımından yüksek bölümünde yer almaktadır.

\section{Tartışma ve Sonuç}

Antalya destinasyonu, doğası, tarihi, kültürü, ulaşılabilirliği, etkinlikleri ve imkanları ile gelen turistlere belirli bir hizmet sunmakta ve elde edilen turizm gelirleriyle ülke ekonomisine katkılar sağlamaktadır (TUIK, 2020a; TUIK, 2020b). Bu çalışmada Türkiye'nin önemli destinasyonlarından biri olan Antalya'nın sahip olduğu çekicilik faktörleri, aynı destinasyonda turizm eğitimi alan öğrencilerin bakış açısıyla önem-performans analizi ile değerlendirilmiştir. ÖPA, yönetimsel açıdan bakıldığında kıt kaynakların nasıl verimli kullanılması gerektiği, müşteri memnuniyetinin artırılması ve geliştirilmesi gereken alanların belirlenmesi gibi konularda yol gösteren basit ve kullanışlı bir istatistiksel analiz tekniğidir (Martilla ve James, 1977: 2). Bu teknik sayesinde bilimsel temellere dayalı ve stratejik kararlar alınabilmektedir. Ancak literatürde, ikamelerine nazaran, önem-performans analizinin kullanımına az rastlanmıştır. 
$\mathrm{Bu}$ çalışmada önem-performans analizi ile öğrencilerden, destinasyon çekiciliklerini kendileri için önem sırasına göre sıralamaları istenmiş ve böylece destinasyonun çekici faktörleri önem hiyerarşisi ortaya çıkarılmıştır. Ardından her çekici faktörün performansı öğrenciler tarafından derecelendirilmiştir. $\mathrm{Bu}$ bulguların bir sonucu olarak da önem-performans matrisi oluşturulmuştur. Önem-performans matrisinin sunduğu veriler; bir yandan destinasyon çekici faktörlerin önem ve performans algısının ölçümüne imkân sunarken, diğer yandan turizm sektöründe yer alan kamu ve özel sektör yöneticilerinin ürün yelpazelerini yeniden gözden geçirebilmeleri bakımından önemli sonuçlar ortaya koymaktadır.

Araştırma sonuçlarına göre; öğrencilerin Antalya'da bulunan üniversiteleri tercih etmelerinde Antalya destinasyonunun \% 88,5'i (evet + kısmen) ile etkisinin bulunduğu tespit edilmiştir. Bu oranın yüksek olmasında destinasyonun turizm açısından popülerliğinin ve tanınırlığının etkili olduğu tahmin edilmektedir. Ayrıca hem ÖPA hem açık uçlu cevaplar incelendiğinde altyapı ve ulaşım konusuna dikkat çekilmektedir. Destinasyonun temizliği, yiyecek-içecek işletmelerinin kalitesi ve ulaşım ağının yaygınlığı önem düzeyi yüksek fakat performans düzeyinin düşük olduğu alanlar arasında yer almaktadır. Bu bağlamda bu ifadelerle ilgili alanlara yatırımların artırılması, kaynak aktarımlarının bu alanlara yönlendirilmesi ve daha çok önem gösterilmesi gerektiği sonucu ortaya çıkmaktadır. Doğal güzellikler, kültür (yiyecek, içecek, dil, din), konaklama ve destinasyonun cazip alanları ise önem ve performans açısından yeterli seviyede olduğu görülmektedir. Bu alanların korunması, standartlarının aynı şekilde devam etmesi ve mevcut yatırımların aynı şekilde sürdürülmesi gerektiği sonucuna ulaşılmaktadır. Destinasyondaki yerlere sınırsız ziyaret, danışma hizmetleri, bilgilendirici levha ve simgeler ve ilginç/farklı yerel gelenekler katılımcılar tarafından düşük öneme ve düşük performans düzeyine sahip olduğu görülmektedir. Bu sebeple bu alanlara yapılacak yatırımların daha düşük seviyede tutulması yeterli görülmektedir. İş/ticaret, destinasyonun tarihi ve birden çok alışveriş fırsatının düşük öneme, bununla birlikte yüksek performans düzeyine sahip olduğu görülmektedir. Bu alanların diğer alanlara göre daha az önemli olması, fırsat maliyeti açısından düşünüldüğünde yatırımların daha önemli görülen alanlara yönlendirilebileceği sonucuna ulaşmak mümkündür. Bununla birlikte destinasyon tarihinin önem açısından ortalamaya yakın ve performans açısından yüksek olduğunu da göz ardı etmemek gerekmektedir.

$\mathrm{Bu}$ çalışmanın sonuçları, literatürde yapılmış başka çalışmaların sonuçları ile de birbirini desteklemektedir. Çetingöz ve Artuğer (2014) Antalya'da yabancı turistler üzerinde yapmış olduğu çalışmada destinasyon temizliğinin, güvenliğin ve doğal güzelliklerin önemli olduğunu, Nikjoo ve Ketabi (2015) İstanbul ve Antalya'ya seyahat edecek İranlı turistler üzerinde yapmış olduğu çalışmada rekreatif faaliyetlerin olduğu, kültürel ve tarihi bir destinasyonun onlar için çekici özellikler olduğunu, Sarı ve Ahmadlı (2018) Azerbaycanlı turistlerin konaklama ve seyahat tercihinde tatil yapılan dönemdeki destinasyonun coğrafi özelliklerine önem verildiğini ifade etmişlerdir. Albayrak ve Çömen (2018) kaya tırmanışı yapmak için Antalya destinasyonuna gelen turistler üzerinde yapmış olduğu çalışmada ÖPA'yı uygulamışlardır. Bu çalışmada manzara, sessizlik, hizmet kalitesinin korunması gereken alanlar olduğu ortaya çıkmıştır. Ayrıca tesislerin temizliği üzerine yoğunlaşılması gerektiğini ifade etmişlerdir. Öte yandan Güneş (2016)'in Antalya destinasyonunun kalite unsurlarının ve boyutlarının belirlenmesi bağlamında yapmış olduğu önem-performans analizinde elde edilen bulgulara göre; güvenlik, ulaşım ve enformasyon boyutları yoğunlaşılması gerekenler, yiyecek-içecek olanakları, 
deniz-kum-güneş ve kaynaklar boyutları korunması gerekenler, fiyat ve toplum boyutları düşük öncelikliler, etkinlik ve konaklama olanakları boyutları kaçınılması gereken olası aşırılıklardır. Albayrak ve Caber (2011)'in yapmış olduğu çalışmada ÖPA'nın tekniğine ve özelliklerine yer vermiş ve bir uygulamasını sunmuşlardır. Manavgat ve Side bölgesinde yapılan çalışmada konaklamanın korunması gerektiğini, sağlık ve hijyen konusuna yoğunlaşılması gerektiğini, alışveriş konusunda düşük önem verilmesi gerektiğini ve son olarak ulaşım konusunun öneminin düşük fakat performansının yüksek olduğunu ifade etmiş̧lerdir. Fakat bu çalışmada ulaşım ağının yaygınlığı yüksek önem, düşük performans düzeyinde olduğu sonucuna ulaşılmıştır. Bu durum Antalya nüfusunun giderek artması ve gelen turist sayısının artış göstermesi ulaşılabilirliğin önemini artırmıştır. Bu bağlamda performans olarak ulaşılabilirliğin düşük seviyeye gelmesi yapılan yatırımların yetersiz kaldığını göstermektedir.

Sonuç olarak Antalya ili, turizm çeşitliliği bakımından özgün ve zengin bir destinasyondur. $\mathrm{Bu}$ çalışma, Antalya destinasyonun çekicilikleri hakkında hem araştırmacı hem de turistik tüketici olan ve turizm eğitimi alan öğrencilerin görüşlerinin destinasyonun önem ve performansının ÖPA aracılığıyla ortaya konulması açısından büyük bir önem taşımaktadır. Yapılan bu çalışmanın söz konusu destinasyonun diğer destinasyonlarla rekabet edebilir ve sürdürülebilir olmasında destinasyon yönetimine ve paydaşlarına karar alma süreçleri ile ilgili önemli bilgiler verdiği ve katkılar sağlayacağı düşünülmektedir.

\section{Araştırmanın Sınırıılı̆ğ ve Öneriler}

Araştırmanın sınırlılığını, Antalya ilinde bulunan Akdeniz Üniversitesi’nde 2019 Eylül-Kasım ayları arasında eğitim alan turizm öğrencileri oluşturmaktadır. Gerek coğrafi bakımdan gerekse turizm çekicilikleri bakımından büyük çeşitlilik gösteren turistik destinasyonda sahip olunan çekici özellikler ve sunulan hizmetlere ilişkin, ilde öğrenim gören diğer üniversite öğrencilerine de anket uygulanması ve önem-performans analizi yöntemiyle analiz edilerek mevcut durumun ortaya çıkarılması gerekmektedir. Aynı çalışma farklı bir destinasyonda, farklı bir örneklem grubunda, farklı bir zamanda farklı sonuçlar ortaya çıkarabilir. Alanyazına ilişkin ileriki çalışmalarda, iki destinasyonun önemperformans analizine bakılarak karşılaştırmalar yapılabilir. Aynı çalışma üçüncü yaş grubuna ait olan bireyler üzerinde gerçekleştirilebilir ve böylece genç grup ile üçüncü yaş grubuna ait araştırma sonuçları değerlendirilebilir. Benzer çalışma aynı üniversitede eğitim veren akademisyenlere de uygulanabilir. Turizm eğitimi veren akademisyenler ile turizm eğitimi alan öğrencilerin analizleri karşılaştırılabilir.

\section{Notlar}

1. Bireylerin boş zamanlarında gönüllü olarak doğrudan ve fiziksel katılım sağladığı, sonucunda da ruhsal ve / veya fiziksel yenilenme yaşadığı faaliyetlerin tamamını kapsar (Ceylan ve Somuncu, 2020: 29). 


\begin{tabular}{ccc} 
Coğrafi Bilimler Dergisi & Coğrafi \\
Bilimler & Dergisi \\
\hline
\end{tabular}

\section{The Importance-Performance Analysis of Pull Factors Affecting the Touristic Destination's Choice of Students in the Tourism Faculty of Akdeniz University}

Zeki Akıncı $^{\mathrm{a}}$, Dilek Aybar*b ${ }^{* \mathrm{~b}}$ Altan Demirel $^{\mathrm{c}}$, Dilara Bahtiyar Sar1 ${ }^{\mathrm{c}}$, Emine Nurdan Öksüz $^{\mathrm{d}}$

\section{EXTENDED ABSTRACT}

\section{Introduction}

In their leisure time, people prefer to take on a journey with different motivations such as having fun, self-development, socializing, staying healthy and fit, acquiring knowledge and culture, traveling, and experiencing adventure and excitement (Cordes, 2013). In this context, travel motivation is the starting of people's decision-making process for traveling with many stages (Mansfeld, 1992). At this point, the push factors related to the inner travel motivation of the individual lead him/her to travel. This process is followed by obtaining information about pull factors related to external travel motivation that will meet the expectations of the person with internal travel motivation, as well as evaluating and choosing the most suitable one among the destination alternatives.

Push and pull factors play an important role in determining the elements that cause purchasing behavior of people in the travel decision making process (Kim, Lee and Klenosky, 2003). These push and pull factors provide a simple and intuitive approach towards understanding the motivation that causes specific tourist behavior. The push factors, called intrinsic travel motivations, are internal factors that push people away from their homes and provide the first motivation to travel (Schott, 2004). Meisel and Cottrell (2003) state that desire to escape, rest and relaxation are among the general push factors.

While the push factors have intuitive power to affect travel-related decision making in individual's life, pull factors are concrete reasons for preferring one destination over another. On the other hand, Crompton (1979) revealed that the push factors do not only explain a vacationer's curiosity to go on vacation, but can also work with pull factors in suggesting a potential destination for tourist. In addition to economic, socio-cultural and demographic features, destination pull factors that can meet

\footnotetext{
*Sorumlu Yazar/Corresponding Author: Dilek Aybar, dilekaybar@akdeniz.edu.tr

a Akdeniz University, Faculty of Tourism, The Depatment of Tourism Management, Antalya, Turkey, https://orcid.org/00000001-8643-3429.

${ }^{\mathrm{b}}$ Akdeniz University, Faculty of Tourism, The Depatment of Tourism Management, Antalya, Turkey, https://orcid.org/00000002-1335-3601.

C Antalya AKEV University, Vocational School, Travel-Tourism and Leisure Services Department, Tourist Guiding Program, Antalya, Turkey, https://orcid.org/0000-0002-1010-4116.

ฯ Gaziantep University, Vocational School of Tourism and Hotel Management, Hotel, Restaurant and Catering Services of the Department, Gaziantep, Turkey, https://orcid.org/0000-0002-0645-0585.

d Akdeniz University, Demre Dr. Hasan Ünal Vocational School of Higher Education, Tourism, Travel and, Entertainment Services, Antalya, Turkey, https://orcid.org/0000-0002-6091-3069.
} 
individuals push factors for travel can have decisive impact on tourist's destination choice and purchasing decisions (Demir, 2010). According to Uysal, Li, and Sirakaya-Turk (2008), historical sources, natural environment, socio-physical structure and similar elements represent pull factors. In addition to previous studies in the literature and considering the perspective of tourism students, importance and performance analysis of destination pull factors was conducted, omitting the push ones.

Antalya destination, the subject in the current study, is a coastal city in the south of Turkey. Antalya's coasts, which are among the cleanest and most beautiful coasts of the country, constitute $35 \%$ $(450 \mathrm{~km})$ of the Mediterranean coastline (1,577 km) (Sar1 and Aligil, 2016). It is one of the Turkey's and world's most important destinations due to its modern infrastructure and superstructure, as well as with its unique natural and historical beauty.

\section{Methodology}

\section{Importance-performance analysis}

Importance-Performance Analysis (IPA) was first used in the automobile industry (Martilla and James, 1977). Later on it has also advanced in the tourism industry, more specifically travel and hospitality (Go and Zhang, 1997; Hollenhorst, Olson and Fortney, 1986), in order to measure the importance of customer satisfaction and service features. The IPA was used in the evaluation of tourism destinations by Pike and Ryan (2003), in evaluating the dining experience qualities of restaurants by $\mathrm{Hu}$, Chen and $\mathrm{Ou}$ (2009), in formulating and evaluating tourism policy by Evans and Chon (1989), in defining tourists' perceptions about the hotel industry by Lewis (1985) and in determining tools to increase customer satisfaction by Almanza et al. (1994).

As known, importance-performance analysis (IPA) is widely used to examine the relationship between perceived importance and performance in tourism destinations. The IPA analysis is based on the comparison of the importance of the features of subject matter or dimension and the perceptions of performance related to these features on a matrix. In this way, more accurate decisions can be made in administrative issues, especially the areas in which limited resources will be transferred (Albayrak and Caber, 2011). According to Martilla and James (1977), the IPA system defines the action grades that business executives should consider. The system consists of four quadrants (see Figure 1).

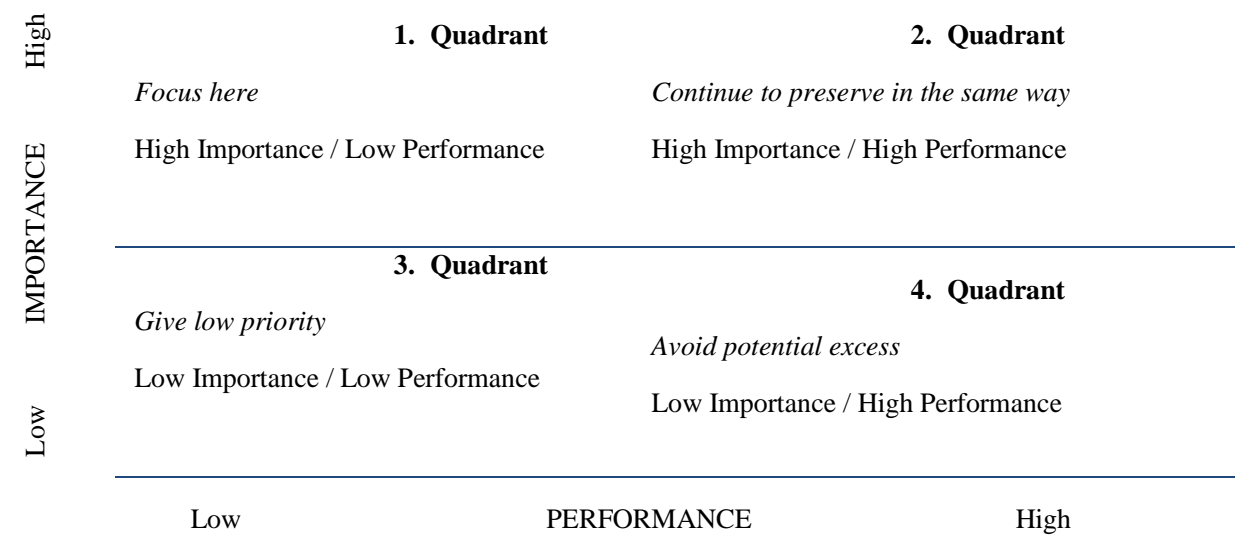

Figure 1. Importance-performance analysis 
The prepared survey was conducted on a voluntary basis among students studying in tourismrelated departments at Akdeniz University. In the first part of the survey, questions related to demographic features are included. In the second part, 24 statements about the factors regarding the importance and performance perceptions of the features and services provided for Antalya destination are included. In this part, participants were asked to evaluate in the range from very bad (1) to very good (5). For this purpose, the survey was applied to 426 tourism students (from 2332 students at total) between September and November 2019. SPSS 22.0 package program was used for the analysis of the obtained surveys.

\section{Result}

Table 1: The importance and performance averages of all expressions

\begin{tabular}{|c|c|c|c|}
\hline \multirow{2}{*}{\multicolumn{2}{|c|}{ Expression Used }} & \multirow{2}{*}{$\begin{array}{c}\text { Importance } \\
\text { Average }\end{array}$} & \multirow{2}{*}{$\begin{array}{c}\text { Performance } \\
\text { Average }\end{array}$} \\
\hline & & & \\
\hline 1. & Natural Beauties & 4,06 & 4,40 \\
\hline & $\begin{array}{l}\text { Unlimited visits to the places in the } \\
\text { destination }\end{array}$ & 3,54 & 3,44 \\
\hline 3. & Culture (food, drink, language, religious) & 3,80 & 3,83 \\
\hline & Destination's history & 3,58 & 3,95 \\
\hline & Business / commerce & 3,39 & 3,68 \\
\hline & Hospitality & 3,83 & 3,93 \\
\hline & Destination's smashing areas & $3,87 * *$ & $4,10 * *$ \\
\hline & Interesting/different local traditions & 3,55 & 3,49 \\
\hline & Multiple shopping opportunaties & 3,45 & 3,84 \\
\hline & Destination's cleanliness & 3,80 & 3,59 \\
\hline & $\begin{array}{l}\text { Quality of food and beverage } \\
\text { establishments }\end{array}$ & 3,77 & 3,54 \\
\hline & Destination information services & $3,42^{*}$ & $3,23 *$ \\
\hline & Informative signs and symbols & 3,58 & 3,53 \\
\hline & Widespread transportation network & 3,84 & 3,64 \\
\hline
\end{tabular}

**highest average value * lowest average value

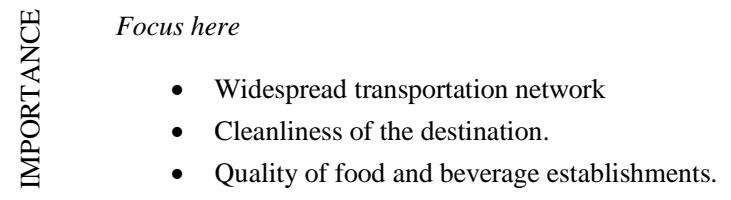

Give low priority

- Unlimited visits to places in the destinations.

- Interesting / different local traditions.

- Destination information services.

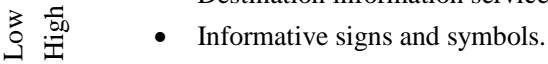

Continue to preserve in the same way

- Natural beauties.

- Culture

- Accommodation.

- Attractive areas of the destination.

Avoid potential excess

- Business / commerce.

- History of the destination.

- Multiple shopping opportunities.

Figure 2: Importance and performance matrix of destination 


\section{Discussion}

In this study, the pull factors of Antalya, one of Turkey's most important destinations, are evaluated with the importance-performance analysis from the perspective of tourism students, receiving their tourism education in the same destination. The fact that importance-performance analysis method has been used less in the literature compared to its substitutions is the reason why this method is used. The most important reasons for choosing Antalya as the application area of the research are; being one of the important destinations of Turkey, having the power to represent the Mediterranean region, being a sufficient destination in terms of income, number of tourists and accommodation capacity, and being an effective city in the university preferences of students. Students were considered as tourists in tourism destination studies due to the reasons such as spending time in the touristic place without returning home during a long vacation for learning purposes and participating in touristic activities in their spare time (Abdullateef and Biodun, 2014). Olcay and Doğan (2015) state that students who have left their place of residence for at least 24 months for university education and settled in another city can also be qualified as potential tourists, and the rate of recommending the city to others positively affects the image of the city. Since it is important and necessary to handle scientific research on the destination from the perspective of different stakeholders (Ayaz and Bakar, 2020), the students of the Faculty of Tourism of Akdeniz University, which provides the oldest higher education service in Antalya, were chosen as the sample of the research.

According to the research results; it has been determined that the Antalya destination has an effect of $88.5 \%$ (yes + partially) in the students' preference of the universities in Antalya. It is estimated that the popularity and recognition of the destination are effective at this high rate. In addition, when both IPA and open-ended answers are examined, attention is drawn to infrastructure and transportation. Cleaning of the destination, quality of food and beverage establishments and widespread transportation network are among the areas with high levels of importance but low performance. In this context, it is the result of increasing investments in the fields related to these expressions, directing the resource transfers to these fields and paying more attention. It is seen that the attractiveness of the destination, natural beauties, culture (food, drink, language, religion), and accommodation are sufficient in terms of importance and performance. It is concluded that these areas should be protected, standards should be hold in the same way and existing investments should be maintained in the same way. It is seen that unlimited visits to places in the destination, interesting / different local traditions, destination information services and informative signs and symbols have low importance and low performance level by the participants. For this reason, it is sufficient to keep the investments in these areas at a lower level. Business / commerce, the history of the destination and multiple shopping opportunities seem to have low significance, but high-performance level. It is possible to reach the conclusion that these areas are less important than other areas, and considering the opportunity cost, investments can be directed to more important areas. However, it should not be overlooked that, the destination's history is close to average in terms of importance and high in performance. 


\section{Conclusions}

Antalya destination is a unique and rich destination in terms of tourism diversity. With IPA, this study is of great importance in terms of revealing the importance and performance about the attractions of Antalya destination, by students who are both researchers and touristic consumers. It is thought that this study will provide important information and contributions to the destination management and its stakeholders regarding decision-making processes in terms of competitiveness and sustainability of the mentioned destination.

The same study may produce different results at a different destination, and sample group, as well as at a different time. In future studies on the literature, comparisons can be made by viewing the importance-performance analysis of the two destinations.

\section{Referanslar/References}

Abdullateef, A.O., Biodun, A.B. (2014). Are international students tourists?, Int. J. Business and Globalisation, 13 (3), 298 306. doi:10.1504/IJBG.2014.064677

Albayrak, T., Caber, M. (2011). Önem-performans analizi: destinasyon yönetimine dair bir örnek. Ege Akademik Bakış, 11 (4), 627-638. 30.12.2021 tarihinde https://www.acarindex.com/dosyalar/makale/acarindex-1423876864.pdf adresinden alınd.

Albayrak, T., Çömen, N. (2018). Kaya tırmanışı yapan turistlerin destinasyon değerlendirmeleri: Geyikbayırı, Antalya örneği. Anatolia: Turizm Araştırmaları Dergisi, 29 (2), 209-220. doi: 10.17123/atad.488289

Almanza, B. A., Jaffe, W., Lin, L. (1994). Use of the service attribute matrix to measure consumer satisfaction. Hospitality Research Journal, 17 (2), 63-75. doi: 10.1177/109634809401700207

Alvarez, M., (2007). Destination Quality. Service Quality, der. Gümüsoglu, S. ve Dig., Ankara: Detay Yayınc1lık.

Antalya İli. 20.06.2019 tarihinde https://en.wikipedia.org/wiki/Antalya_Province adresinden alınd1.

Arıtan, T., Akyüz, A.M. (2015). Tüketicilerin otomobil markalarına yönelik marka sadakatleri ve tercihleri üzerine bir araştırma. Uluslararası Yönetim Ikktisat ve Işsletme Dergisi, 11 (26), 195-220. doi: 10.17130/ijmeb.2015.11.26.947

Ayaz, N., Bakar, R. (2020). Üniversite öğrencilerinin destinasyon imajı algısı: Sinop ili örneği. Journal of Humanities and Tourism Research, 10 (3), 610-626. doi: 10.14230/johut861

Bacon, D.R. (2003) A comparison of approaches to importance-performance analysis. International Journal of Market Research, 45 (1), 55-71. doi: 10.1177/147078530304500101

Bağıran, D. (2015). Destinasyon Yenilik Sürecinin Oluşmasında Ă̆ Yapısı ve Bilgi Yönetiminin Rolü. Doktora Tezi. Dokuz Eylül Üniversitesi, Sosyal Bilimler Enstitüsü, Turizm İşletmeciliği Ana Bilim Dalı, Turizm İşletmeciliği Programı. İzmir. $\quad$ https://www.apikam.org.tr/YuklenenDosyalar/Dokumanlar/e986d55e-6f54-418f-a6aea778135608df537112.pdf adresinden alınd1.

Bahar, O., Kozak, M. (2012). Turizm Ekonomisi (4. Baskı). Ankara: Detay Yayıncılık.

Bruyere, B.L., Rodriquez, D.A., Vaske, J. J. (2002) Enhancing importance-performance analysis through segmentation. Journal of Travel \& Tourism Marketing, 12 (1), 81-95. doi: 10.1300/J073v12n01_05

Buckley, C., Hynes, S., Mechan, S. (2012) Supply of an ecosystem service-farmers' willingness to adopt riparian buffer zones in agricultural catchments. Environmental Science \& Policy, 24, 101-109. doi: 10.1016/j.envsci.2012.07.022

Buhalis, D. (2000). Marketing the competitive destination of the future. Tourism Management. 21 (1), 97-116. doi: $10.1016 / \mathrm{S} 0261-5177(99) 00095-3$

Ceylan, S., Somuncu, M. (2020). Turizm alanlarındaki ikinci konutların rekreasyon amaçlı kullanımı: Pelitköy (Burhaniye/Balıkesir) örneği. Coğrafi Bilimler Dergisi/Turkish Journal of Geographical Sciences, 18 (1), 28-56, doi: 10.33688/aucbd.665702

Chien, M. C. (2016). An emprical study on the effect of attractiveness of ecotourism destination on experiential value and revisit intention. Applied Ecology and Environmental Research, 15 (2), 43-53. doi: 10.15666/aeer/1502_043053

Cordes, K.A. (2013). Applications in Recreation \& Leisure: For Today and The Future. 4th ed. Urbana, IL: Sagamore 
Publishing.

Crompton, J. L. (1979). Motivations for pleasure vacation. Annals of Tourism Research, 6 (4), 408-424. doi:10.1016/01607383(79)90004-5

Çakıcı, A. C., Aksu, M. (2007), Çekim yeri seçiminde grup etkisi: Yerli turistler üzerine bir araştırma. Anatolia: Turizm Araştırmaları Dergisi, 18 (2), 183-194.

Çetingöz, B. C., Artuğer, S. (2014). Yabancı turistlerin Antalya' yı tercih etmesinde etkili olan çekici faktörlerin belirlenmesine yönelik bir araştırma. Uluslararası Sosyal Araştırmalar Dergisi, 7 (32), 573-582.

Dann, G. (1977). Anomie, ego-enhancement and tourism, Annals of Tourism Research, 4(4), 184-194. doi: 10.1016/01607383(77)90037-8

Demir, Ş. Ş. (2010). The effects of pull factors on destination choice: A study in Dalyan. Ege Akademik Baklş, 10 (3), 1041 1054. 30.12.2021 tarihinde https://dergipark.org.tr/en/pub/eab/issue/39879/473272\#article_cite adresinden alınd1.

Deng, W., Kuo, Y., Chen, W. (2008) Revised importance-performance analysis: Three-factor theory and benchmarking. The Service Industries Journal, 28 (1), 37- 51. doi: 10.1080/02642060701725412

Evans, M. R., Chon, K. S. (1989). Formulating and evaluating tourism policy using importance-performance analysis. Hospitality Education and Research Journal 13, 203-213. doi: 10.1177/109634808901300320

Friedmann, J., Weaver, C. (1980). Territory and Function, the Evolution of Regional Planning. California: California University Press.

Go, F., Zhang, W. (1997) Applying importance-performance analysis to Beijing as an international meeting destination. Journal of Travel Research, 35 (4), 42-49. doi: 10.1177/004728759703500407

Gunn, C. A. (1994). Tourism Planning (3. ed). Washington: Taylor \& Francis.

Güneş, E. (2016). Destinasyon Seçiminde Etkili Olan Destinasyon Kalite Unsurlarının Analizi: Antalya Örneği. Akdeniz Üniversitesi, Sosyal Bilimler $\quad$ Enstitüsü, $\quad$ Doktora Tezi, Antalya. http://acikerisim.akdeniz.edu.tr/xmlui/handle/123456789/2773 adresinden edinilmiştir.

Hall, C. M., Mitchell, R., Sharples, L. (2003). Consuming Places: The Role of Food, Wine and Tourism in Regional Development. C. M. Hall, L. Sharples, R. Mitchell, N. Macionis \& B. Cambourne (Ed.). in Food Tourism Around The World Development, Management and Markets (New Canadian Library) (25-59).

Hollenhorst S, Olson D., Fortney R (1986) Use of importance performance analysis to evaluate state park cabins: The case of the West Virginia State park system. Journal of Park and Recreation Administration, 10 (1), 1-11. 30.12. 2021 tarihinde https://www.cabdirect.org/cabdirect/abstract/19921850636 adresinden erişildi.

Hsu C.H.C, Byun S., Yang I.S (1997) Attitudes of Korean college students towards quick-service, family-style, and cuisine dining restaurants. Journal of Restaurant and Foodservice Marketing, 2 (4), 65-85. doi: 10.1300/J061v02n04_05

Hu, M. L. M. , Chen, T. K., Ou, T. L. (2009) An importance-performance model of restaurant dining experience. Advances in Hospitality and Leisure, 5, 207-222. doi:10.1108/S1745-3542(2009)0000005015

Karadağ, A., Turut, H. (2013). Üniversite öğrencilerinin kentsel çevre algısı üzerine bir araştırma: İzmir örneği. Coğrafi Bilimler Dergisi, 11 (1), 31-51. doi: 10.1501/Cogbil_0000000141

Ke, L. (2012) The weakness and innovation of China eco-tourism. Physics Procedia, 25, 953-957. doi: 10.1016/j.phpro.2012.03.183

Keyt, J. C. , Yavas, U., Riecken, G. (1994) Importance-performance analysis: A case study in restaurant positioning. International Journal of Retail and Distribution Management, 22 (5), 35-40. ISSN: 0959-0552

Kim, S. S., Lee, C. K., Klenosky, D. B. (2003). The influence of push and pull factors at Korean national parks, Tourism Management, 24 (2), 169-180. doi: 10.1016/S0261-5177(02)00059-6

Kim, J. Hyeong, (2014). The antecedents of memorable tourism experiences: The development of a scale to measure the destination attributes associated with memorable experiences. Tourism Management, 44, 34-45. doi: 10.1016/j.tourman.2014.02.007

Klenosky, D. B. (2002). The "pull" of tourism destinastions: A means-end investigation, Journal of Travel Research, 40 (4), 385-395. doi: 10.1177/004728750204000405

Kozak, M. (2002). Destination benchmarking. Annals of Tourism Research, 29 (2), 497-519. doi: 10.1016/S01607383(01)00072-X 
Kültür ve Turizm Bakanlığı (KTB, 2020). Turizm İstatistikleri. 04.03.2020 tarihinde https://yigm.ktb.gov.tr/TR-9851/turizmistatistikleri.html adresinden alınmıştır.

Lewis R. C. (1985). Getting the most from marketing research. predicting hotel choice: The factors underlying perception. The Cornell Hotel and Restaurant Administration Quarterly, 26 (3), 82-96. doi: 10.1177/001088048502500415

Lo, A. Y., Jim, C. Y. (2015). Protest response and willingness to pay for culturally significant urban trees: Implications for Contingent Valuation Method. Ecological Economics, 114, 58-66. doi: 10.1016/j.ecolecon.2015.03.012

Mansfeld, Y. (1992). From Motivation to Actual Travel. Annals of Tourism Research, 19 (3), 399-419. doi: 10.1016/01607383(92)90127-B

Martilla, J. A., James, J. C. (1977). Importance-performance analysis. Journal of Marketing, 41 (1), 77-79. doi: $10.1177 / 002224297704100112$

Martin, D. W. (1995). An importance-performance analysis of service providers' perception of quality service in the hotel industry. Journal of Hospitality and Leisure Marketing, 3 (1), 5-17. doi: 10.1300/J150v03n01_02

Meisel, C., Cottrell, S. (2003). Differences in Motivations and Expectations of Divers in The Florida Keys, In: Murdy J. editor. Proceedings of the Northeastern Recreation Research Symposium. Newtown Square PA: 393-401.

Nikjoo, A.H., Ketabi, M. (2015). The Role of Push and Pull Factors in The Way Tourists Choose Their Destination. Anatolia: An International Journal of Tourism and Hospitality Research, 26 (4), 588-597.

Obonyo, G.O., Ayieko, M.A., Kambona, O.O. (2013). An importance-performance analysis of food service attributes in gastrotourism development in western tourist circuit, Kenya. Tourism and Hospitality Research, 12 (4), 188-200.

Oh, H., Uysal, M., Weaver, A. P. (1995). Product bundles and market segments based on travel motivations: A canonical correlation approach. Int. J. Hospitality Management, 14 (2), 123-137. doi:10.1016/0278-4319(95)00010-A

Olalı, H. (1990). Turizm Politikasl ve Planlaması. İstanbul: Yön Ajans.

Olcay, A., Doğan, G. (2015). Bir destinasyon olarak Gaziantep şehir imajına yönelik öğrenci görüşleri. Bolu Abant İzzet Baysal Üniversitesi Sosyal Bilimler Enstitüsü Dergisi, $15 \quad$ (2), 235-268. 11.01.2022 retrieved from https://dergipark.org.tr/tr/pub/basbed/issue/16844/432070

Öter, Z., Özdoğan, O, N. (2005). Kültür amaçlı seyahat eden turistlerde destinasyon imajı: Selçuk-Efes örneği. Anatolia: Turizm Araștırmalarl Dergisi, $\quad 16 \quad$ (2), $\quad 127-138 . \quad 30.12 .2021 \quad$ tarihinde https://dergipark.org.tr/tr/pub/atad/issue/16796/174475\#article_cite adresinden alınmıştır.

Pike, S., Ryan, C. (2003). Dimensions of Short Break Destination Attractiveness - A Comparison of Cognitive, Affective and Conative Perceptions. In: CAUTHE (Council for Australian University Tourism and Hospitality Education) Annual Conference, Southern Cross University, Coffs Harbour, February 2003.

Raosoft. (2019). Sample Size Calculator, 27.12.2019 tarihinde http://raosoft.com/samplesize.html adresinden alınmıştır.

Sarı, C., Ahmadlı, K. (2018). Azerbaycanlı Turistlerin Destinasyon Seçiminde Önemli Olan Coğrafi Faktörler. Bekir Çınar, Cengiz Şahin, Selahattin Avşaroğlu, Erkan Akgöz (Ed.), Sosyal ve Beşeri Bilimler Çalışmaları 2018 içinde (85-91), Çizgi Kitabevi.

Sarı, C., Aligil, M. (2016). Konaklama tesisi yöneticilerinin alternatif turizme dair görüşleri: Doğu Antalya (Side) turistik gelişim projesi bölgesi örneği. Atatürk Üniversitesi Sosyal Bilimler Enstitüsü Dergisi, 20 (4), 1649-1663. 30.12.2021 tarihinde https://dergipark.org.tr/tr/pub/ataunisosbil/issue/26966/283422\#article_cite adresinden erişildi.

Schott, P. K. (2004). Across-product versus within-product specialization in international trade. The Quarterly Journal of Economics, 119 (2), 647-678. doi: 10.1162/0033553041382201

Silva, F. H., Fernandes, P. O. (2011). Importance-performance analysis as a tool in evaluating higher education service quality: The empirical results of ESTiG (IPB). In In the 17th International Business Information Management Association Conference (s. 306-315).

Şahin, H., Bekir, H. (2016). Üniversite öğrencilerinin engellilere yönelik tutumlarının belirlenmesi. Türkiye Sosyal

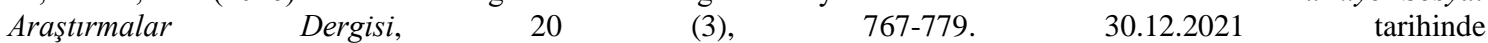
https://dergipark.org.tr/tr/pub/tsadergisi/issue/31706/347479\#article_cite adresinden alınmıştır.

Tavşancıl, E. (2005). Tutumların Ölçülmesi ve SPSS ile Veri Analizi. Ankara: Nobel Yayın Dağıtım.

Turizmaktuel. 04.03.2020 tarihinde https://www.turizmaktuel.com/haber/antalya-da-kac-otel-ne-kadar-yatak-var adresinden alındi.

Türkiye İstatistik Kurumu (TUIK, 2020a). Nüfus ve Vatandaşlık Işsleri Genel Müdürlüğü Haber Bülteni. Say1:33705. 
Türkiye İstatistik Kurumu (TUIK, 2020b). Turizm Haber Bülteni. Sayı:33669.

Ulama, Ş. (2015). Turizm tanıtım broşürlerinde destinasyon imajı analizi: Türkiye örneği. Bartın Üniversitesi İ.İ.B.F. Dergisi, 6 (11), 231-246.

UNWTO - A Practical Guide to Tourism Destination Management. 20.06.2019 tarihinde https://www.eunwto.org/doi/book/10.18111/9789284412433_adresinden alınd1.

Ural, A., Kılıç, G. (2006). Scientific Research Process and Data Analysis with Spss. (2. Press). Detay Publishing, Ankara.

Uysal, M., Li, X., Sirakaya-Turk, E. (2008). Push-Pull Dynamics in Travel Decisions. Haemoon Oh (Ed.), in Handbook of Hospitality Marketing Management. 412-439.

Ünal, A., Binbaşığlu, H. (2015). Bir şehrin pazarlanması ve marka şehir olmasına yerel sağlık kuruluşlarının katkısı: İnönü üniversitesi karaciğer nakli enstitüsü örneği. İnönü Üniversitesi Kültür ve Sanat Dergisi, 1 (2), 1-10. 30.12 .2021 tarihinde https://dergipark.org.tr/tr/download/article-file/716470 adresinden erişilmiştir.

Yazıcıoğlu, Y., Erdoğan, S. (2004). SPSS Uygulamalı Bilimsel Araştırma Yöntemleri. Ankara: Detay Yayıncılık.

Yousefi, M., Marzuki, A. (2012). Travel motivations and the influential factors: The case of Penang, Malaysia. Anatolia: An International Journal of Tourism and Hospitality Research, 23 (2), 169-176. doi: 10.1080/13032917.2012.662906 